\title{
Effect of some factors on cow longevity
}

\author{
ANNA SAWA and MARIUSZ BOGUCKI \\ Department of Cattle Breeding, Faculty of Animal Breeding and Biology, University of Technology and Life Sciences in \\ Bydgoszcz, Bydgoszcz, Poland
}

\begin{abstract}
Longevity (lifespan, length of productive life, number of calvings) was analysed in 25231 cows that first calved in 1988 and 2000 in the Pomerania and Kujawy regions in Poland. GLM procedures of the SAS package were used in the statistical calculations. Longevity of cows that first calved in 2000 was found to improve in relation to that of cows that were first milked in 1988. The lifespan and length of productive life increased the most (by about 1 year) in herds of up to 20 cows, in herds with the lowest production level (by about 0.85 years), in herds of cows that first calved before 24 months of age up (by about 1 year) and in herds of cows that yielded $4000-7000 \mathrm{~kg}$ milk as first calvers (by about 0.5 years). Shortening the length of productive life in cows culled for low milk production (by 0.3 years) is probably one of the reasons for considerable production progress attained in cows in recent years. Age of cows at first calving and first lactation milk yield were significantly correlated to cow longevity.
\end{abstract}

Keywords: cows, longevity, age at first calving, first lactation milk yield

\section{Zusammenfassung}

\section{Einfluss ausgewählter Faktoren auf die Langlebigkeit von Kühen}

Untersucht wurden einige Faktoren wie Herdengröße, Erstlaktations-, Herdenleistung und Abkalbealter auf die Langlebigkeit von 25231 Kühen gemessen an Lebens- und Nutzungsdauer sowie Zahl der Abkalbungen. Es konnte bei den erstmals kalbenden Tieren für den Zeitraum von 1988 bis 2000 eine Verbesserung der Langlebigkeit festgestellt werden. Diese Verbesserung der Lebens- und Nutzungsdauer war vor allem in Herden $<20$ Kühe (um etwa 1 Jahr), in Herden mit niedrigem Produktionsniveau (um etwa 0,85 Jahr), bei Tieren, die ein Erstkalbealter $<24$ Monate hatten (um etwa 1 Jahr), und bei Kühen deren Erstlaktationsleistung 4000 bis $7000 \mathrm{~kg}$ Milch (um etwa 0,5 Jahr) betrug zu beobachten. Die Verringerung der Nutzungsdauer (um 0,3 Jahre durch Merzung von Kühen mit Minderleistungen ist wahrscheinlich eine der Ursachen des Produktionsfortschrittes der letzten Jahre. Signifikante Zusammenhänge konnten für das Erstkalbealter, die Erstlaktationsleistung und die Langlebigkeit nachgewiesen werden.

Schlüsselwörter: Kühe, Langlebigkeit, Erstkalbealter, Erstlaktationsleistung 


\section{Introduction}

The life span and the longevity of cows have great importance in cattle husbandry (DAKAY et al. 2006). The term »ongevity" refers to long duration of life that ends in natural death. However, most farm animals have no opportunity to achieve longevity because they are slaughtered before natural death. Longevity in cows can be measured by their lifespan (from birth to culling from the herd), length of productive life (from first calving to culling), and survival to a certain age, calving or lactation. DUCROCQ et al. (1988) distinguish between actual survival to a certain age (i.e. the cow's ability to stay in the herd for a certain time) and functional survival related to forced culling.

Based on the findings of other authors, SKRZYPEK (1978) considers the age of about 11 years as reflecting dairy cows' vitality while reporting that the world's oldest cow lived to 35 years of age. Many authors (LITWIŃCZUK et al. 1984, SAWA 1998, JUSZCZAK et al. 2001, WROŃSKI et al. 2003, SOBEK et al. 2006) have shown that the lifespan of cows in Poland has tended to decrease over many years. A similar situation exists in other countries (FREYER and ERHARDT 2000). Low heritability of longevity $\left(h^{2}=0.03-0.1\right)$ suggests that genetic improvement of this trait may be a slow process (ŻARNECKI et al. 1997, SAWA 1998, MESZAROS et al. 2008).

In breeding practice, growing attention is given to the improvement of functional traits that determine the efficiency of rearing dairy cattle (BAUMUNG et al. 2001, HARDER et al. 2004). Among these, important roles are played by life span, length of productive life and fertility (SWALVE 2003). Actual herd life depends on breeders who decide based on cow productivity and general state of health indicating the chance for survival.

The objective of the present study was to analyse the effect of some factors on longevity of the active population of cows from the Pomerania and Kujawy regions in Poland.

\section{Materials and methods}

Longevity (lifespan, length of productive life, number of calvings) was analysed in 25231 cows that first calved in 1988 and 2000 in milk-recorded herds from the Pomerania and Kujawy regions and were culled before 1996 and 2008, respectively.

The effect of the analysed factors on longevity was estimated using analysis of variance according to the following linear model (SAS 2004):

$$
Y=\mu+a_{i}+b_{j}+(a b)_{i j}+e_{i j k}
$$

were $Y$ is the longevity, $\mu$ is the overall mean, $a_{i}$ is the effect of $i$-th year, in which cows calved for the first time $(1988,2000), b_{j}$ is the effect of $j$-th herd size $(\leq 10,10.1-20,20.1-100,100.1-200$ and $>200$ head); or $j$-th herd production level $(\leq 4000,4001-5000,5001-6000$ and $>6000 \mathrm{~kg}$ milk); or $j$-th age of cow at first calving ( $\leq 22,22.1-24,24.1-26,26.1-28,28.1-30,30.1-32$ and $>32$ months); or $j$-th first lactation milk yield $(\leq 4000,4001-5000,5001-6000,6001-7000,7001$ 8000 and $>8000 \mathrm{~kg}$ ); or $j$-th reason for removal from the herd (taking into account the reasons given in SYMLEK records: sold for further breeding, low milk yield, udder diseases, infertility and reproductive diseases, infectious diseases (including leukemia), old age, metabolic and digestive disorders, respiratory diseases, locomotor diseases, accidents, others), $(a b)_{i j}$ is the interaction between year of first calving and herd size (or herd production level, or age at first 
calving, or first lactation milk yield, or reason for removal from the herd), $e_{j j k}$ is the random error of observation.

The significance of differences was analysed using the Scheffe test.

\section{Results}

The longevity of cows that first calved in 2000 improved in relation to that of cows that first calved in 1988 (Table 1). One of the reasons for the increased length of productive life and the greater number of calvings in cows that first calved in 2000 is that their growth period was shorter (24.4 months) than that of cows that first calved in 1988 ( 25.9 months). It is worth noting that the proportion of live cows that were used for over 8 years was $1.7 \%$ in the group of cows from 1988 and $3.9 \%$ in the group of cows from 2000.

Table 1

Effect of year of first calving on cow longevity Jahr der Erstabkalbung und Langlebigkeit

\begin{tabular}{lccccc}
\hline Year & & N of cows & \multicolumn{2}{c}{ Length of } & N of calvings \\
& & & life, years & productive, years & \\
\hline Culled cows & 1 & 14785 & 5.18 & 3.01 & 2.77 \\
1988 & 2 & 9797 & 5.74 & 3.28 & 3.46 \\
2000 & $1-2^{* *}$ & $1-2^{* *}$ & $1-2^{* *}$ & & \\
Significance of differences & & & & & 7.91 \\
Live cows & 1 & 251 & 10.74 & 8.44 & 6.82 \\
1988 & 2 & 398 & 10.60 & 8.39 & \\
2000 & $1-2^{* *}$ & $1-2^{*}$ & $1-2^{* *}$ & & \\
Significance of differences &
\end{tabular}

** $P \leq 0.01,{ }^{*} P \leq 0.05$

The longevity of cows in the populations studied showed statistically significant differences within treatment factors analysed (Table 1, 2, 3, 4, 6, 8). Between 1988 and 2000, the greatest increase in longevity traits (about 12 months of age and productive life) was found in herds of $\leq 10$ and 10.1-20 cows (Table 2). Cows that first calved in 1988 were characterized by the shortest lifespan and the lowest number of calvings when used in herds of 100.1-200 cows. Meanwhile, their age mates from smaller herds showed significantly better longevity, with the increase in the number of cows per herd from $\leq 10$ to $100.0-200$ head having a beneficial effect on longevity. In cows that first calved in 2000, longevity traits tended to deteriorate as the number of cows per herd exceeded 20. In addition, positive changes were found for the proportion of cows used in herds of different sizes. While among cows that first calved in 1988 as many as $22.6 \%$ were used in herds of $\leq 10$ cows and only $5.1 \%$ in herds of $>200$ cows, these proportions for cows that first calved in 2000 were $10.9 \%$ and $16 \%$, respectively.

Herd production level reflects many (mainly environmental) factors and often serves to measure the quality of rearing conditions. In herds with $\leq 4000 \mathrm{~kg}$ milk yield, about $32 \%$ cows were first milked in 1988 and only $6.5 \%$ in 2000, while in herds with $>6000$ kg milk yield only $5 \%$ cows were first milked in 1988 and as many as 35.5\% in 2000 (Table 3). In cows that first calved in 1998, longevity improved with increasing herd milk production. Among the 
cows that first calved in 2000, longevity was highest in cows from herds with $4001-5000 \mathrm{~kg}$ milk yield, but a further increase in herd production level had a negative effect on longevity. Cows that first calved in 2000 achieved greater longevity compared to those calving in 1988, but these differences decreased as herd production level increased, e.g. from 0.9 years of productive life ( $\leq 4000 \mathrm{~kg}$ production level) to 0.23 years ( $>6000 \mathrm{~kg}$ production level).

Table 2

Effect of year of first calving and herd size on cow Jahr der Erstabkalbung, Herdengröße und Langlebigkeit

\begin{tabular}{|c|c|c|c|c|c|c|}
\hline \multirow[t]{2}{*}{ Year } & \multirow[t]{2}{*}{$\mathrm{N}$ of cows per herd } & & \multirow[t]{2}{*}{$\mathrm{N}$ of cows } & \multicolumn{2}{|c|}{ Length of } & \multirow[t]{2}{*}{$\mathrm{N}$ of calvings } \\
\hline & & & & life, years & productive, years & \\
\hline \multirow[t]{5}{*}{1988} & $\leq 10$ & 1 & 3349 & 5.15 & 2.70 & 2.92 \\
\hline & $10.1-20$ & 2 & 3182 & 5.23 & 2.76 & 3.01 \\
\hline & 20.1-100 & 3 & 5007 & 5.35 & 2.92 & 3.18 \\
\hline & $100.1-200$ & 4 & 2487 & 4.86 & 2.58 & 2.77 \\
\hline & $>200$ & 5 & 760 & 5.08 & 2.82 & 2.96 \\
\hline \multirow[t]{5}{*}{2000} & $\leq 10$ & 6 & 1072 & 6.03 & 3.85 & 3.65 \\
\hline & $10.1-20$ & 7 & 2541 & 6.14 & 3.95 & 3.74 \\
\hline & 20.1-100 & 8 & 2295 & 5.68 & 3.34 & 3.17 \\
\hline & $100.1-200$ & 9 & 2320 & 5.48 & 3.15 & 2.95 \\
\hline & $>200$ & 10 & 1569 & 5.38 & 3.02 & 2.94 \\
\hline \multirow{8}{*}{\multicolumn{4}{|c|}{ Significance of differences }} & $1-3,4,6,7,8,9^{* *}$ & $1-3,6,7,8,9,10^{* *}$ & $1-3,6,7,8^{* *}$ \\
\hline & & & & $1-10^{*}$ & $2,4-6,7,8,9,10^{* *}$ & $2-4,6,7^{* *} ; 2-3^{*}$ \\
\hline & & & & $2-4,6,7,8,9^{* *}$ & $3-4,6,7,8,9^{* *}$ & $3-4,6,7,9,10^{* *}$ \\
\hline & & & & $3-4,6,7,8^{* *}$ & $5-6,7,8^{* *} ; 5-9^{*}$ & $4-6,7,8^{* *}$ \\
\hline & & & & $4-6,7,8,9,10^{* *}$ & $6,7-8,9,10^{* *}$ & $5-6,7^{* *}$ \\
\hline & & & & $5-6,7,8,9^{* *}$ & $8-10^{* *}$ & $6,7-8,9,10^{* *}$ \\
\hline & & & & $6,7-8,9,10^{* *}$ & & \\
\hline & & & & $8-10^{* *}$ & & \\
\hline
\end{tabular}

${ }^{*} P \leq 0.01,{ }^{*} P \leq 0.05$

Table 3

Effect of year of first calving and herd milk production on cow longevity Jahr der Erstabkalbung, Herdenleistung und Langlebigkeit

\begin{tabular}{|c|c|c|c|c|c|c|}
\hline Year & \multicolumn{2}{|l|}{$\begin{array}{l}\text { Herd milk production } \\
\text { level, kg milk }\end{array}$} & $\mathrm{N}$ of cows & \multicolumn{2}{|c|}{ Length of } & $\mathrm{N}$ of calvings \\
\hline \multirow[t]{4}{*}{1988} & $\leq 4000$ & 1 & 4862 & 5.02 & 2.54 & 2.75 \\
\hline & $4001-5000$ & 2 & 6669 & 5.24 & 2.84 & 3.08 \\
\hline & $5001-6000$ & 3 & 2502 & 5.27 & 2.94 & 3.21 \\
\hline & $>6000$ & 4 & 752 & 5.45 & 3.12 & 3.29 \\
\hline \multirow[t]{4}{*}{2000} & $\leq 4000$ & 5 & 638 & 5.83 & 3.44 & 3.31 \\
\hline & $4001-5000$ & 6 & 2214 & 5.92 & 3.60 & 3.42 \\
\hline & $5001-6000$ & 7 & 3467 & 5.73 & 3.48 & 3.33 \\
\hline & $>6000$ & 8 & 3478 & 5.63 & 3.35 & 3.15 \\
\hline \multirow{5}{*}{\multicolumn{4}{|c|}{ Significance of differences }} & $1-2,3,4,5,6,7,8^{* *}$ & $1-2,3,4,5,6,7,8^{* *}$ & $1-2,3,4,5,6,7,8^{* *}$ \\
\hline & & & & $2,3-5,6,7,8^{* *}$ & $2,3-5,6,7,8^{* *}$ & $2-6,7^{* *}$ \\
\hline & & & & $4-6^{* *}$ & $2-4^{*}$ & $3-6^{* *}$ \\
\hline & & & & $4-5,7^{*}$ & $4-6,7^{* *}$ & $6,7-8^{* *}$ \\
\hline & & & & $6-8^{* *}$ & $6-8^{* *}$ & \\
\hline
\end{tabular}

${ }^{*} P \leq 0.01,{ }^{*} P \leq 0.05$ 
In both populations, the lifespan of cows clearly tended to increase with increased age of first calving (Table 4). This fact is supported by a positive correlation between age at first calving and lifespan $\left(r=0.061^{* *}\right.$ for cows calved in 1988 and $r=0.039^{* *}$ for cows calved in 2000) (Table 5). The length of productive life in cows that first calved in 1988 ranged from 2.73 (first calving at $\leq 22$ months) to 2.90 years (first calving at 26.1-28 months) (Table 4). In the other age groups, the length of productive life was found to decrease with increased age of first calving. In cows that were first milked in 2000 , the length of productive life tended to decrease from 4.15 to 2.99 years as the age of first calving increased.

Table 4

Effect of year and age at first calving on cow longevity

Jahr der Erstabkalbung, Erstkalbealter und Langlebigkeit

\begin{tabular}{|c|c|c|c|c|c|c|}
\hline \multirow{2}{*}{$\begin{array}{l}\text { Year } \\
1988\end{array}$} & \multicolumn{2}{|c|}{$\begin{array}{l}\text { Age of cows at first } \\
\text { calving, months }\end{array}$} & \multirow{2}{*}{$\begin{array}{c}\text { N of cows } \\
133\end{array}$} & \multicolumn{2}{|l|}{ Length of } & $\mathrm{N}$ of calvings \\
\hline & $\leq 22$ & 1 & & 4.50 & 2.73 & 3.00 \\
\hline & $22.1-24$ & 2 & 833 & 4.76 & 2.81 & 3.06 \\
\hline & $24.1-26$ & 3 & 2925 & 4.94 & 2.84 & 3.10 \\
\hline & $26.1-28$ & 4 & 3420 & 5.16 & 2.90 & 3.14 \\
\hline & $28.1-30$ & 5 & 2713 & 5.18 & 2.76 & 3.00 \\
\hline & $30.1-32$ & 6 & 1922 & 5.36 & 2.77 & 2.98 \\
\hline & $>32$ & 7 & 2839 & 5.49 & 2.54 & 2.75 \\
\hline 2000 & $\leq 22$ & 8 & 141 & 5.91 & 4.15 & 3.99 \\
\hline & 22.1-24 & 9 & 1121 & 5.75 & 3.79 & 3.65 \\
\hline & $24.1-26$ & 10 & 2888 & 5.68 & 3.58 & 3.42 \\
\hline & $26.1-28$ & 11 & 2196 & 5.70 & 3.45 & 3.26 \\
\hline & $28.1-30$ & 12 & 1487 & 5.77 & 3.35 & 3.15 \\
\hline & 30.1-32 & 13 & 922 & 5.81 & 3.23 & 3.03 \\
\hline & $>32$ & 14 & 1042 & 5.89 & 2.99 & 2.88 \\
\hline \multirow{12}{*}{\multicolumn{3}{|c|}{ Significance of differences }} & \multicolumn{2}{|c|}{$1-7,8,9,10,11,12,13,14^{* *}$} & $1-8,9,10^{* *}$ & $1-8^{*}$ \\
\hline & & & \multicolumn{2}{|c|}{$1-6^{*}$} & $2-8,9,10,11,12^{* *}$ & $2-8,9,10^{* *}$ \\
\hline & & & \multicolumn{2}{|c|}{$2-4,5,6,7,8,9,10,11,12,13,14^{* *}$} & $2-13^{*}$ & $3,4-7,8,9,10^{* *}$ \\
\hline & & & \multicolumn{2}{|c|}{$3-6,7,8,9,10,11,12,13,14^{* *}$} & $3-7,8,9,10,11,12,13^{* *}$ & $5-7,8,9,10,11^{* *}$ \\
\hline & & & \multicolumn{2}{|c|}{$3-4,5^{*}$} & $4-7,8,9,10,11,12^{* *}$ & $6-7^{*}$ \\
\hline & & & \multicolumn{2}{|c|}{$4,5-7,9,10,11,12,13,14^{* *}$} & $4-13^{*}$ & $7-8,9,10,11,12^{* *}$ \\
\hline & & & \multicolumn{2}{|c|}{$4-8^{*}$} & $5,6-8,9,10,11,12,13^{* *}$ & $8-12,13,14^{* *}$ \\
\hline & & & \multicolumn{2}{|c|}{$6-9,10,11,12,13,14^{* *}$} & $7-8,9,10,11,12,13,14^{* *}$ & $9-11,12,13,14^{* *}$ \\
\hline & & & \multicolumn{2}{|c|}{$7-14^{* *} ; 7-12^{*}$} & $8-13,14^{* *} ; 8-12^{*}$ & $10-13,14^{* *}$ \\
\hline & & & & & $9-12,13,14^{* *} ; 9-11^{*}$ & $10-12^{*}$ \\
\hline & & & & & $10,11-14^{* *} ; 10-13^{*}$ & $11-14^{* *}$ \\
\hline & & & & & $12-14^{*}$ & \\
\hline
\end{tabular}

${ }^{*} P \leq 0.01,{ }^{*} P \leq 0.05$

First lactation yield gains importance considering the relatively short length of productive life (3.01 years for the population that first calved in 1988 and 3.28 years for the population that was first milked in 2000) (Table 1). It is worth noting the increased number of cows that exceeded $6000 \mathrm{~kg}$ milk as first calvers: they constituted $44 \%$ of all cows in 2000 compared to just $12 \%$ in 1988 (Table 6). Longevity was differentiated more by first lactation milk yield than by year of calving. The highest increase (by about 0.5 years) in the lifespan of cows that first calved in 2000 compared to those that first calved in 1988 was observed in the groups 
with first lactation yields of $4000-7000 \mathrm{~kg}$ milk. In cows that first calved in 1988, lifespan and length of productive life tended to increase (from 4.84 to 5.69 years and from 2.41 to 3.31 years, respectively) with increasing first lactation milk yield. Among cows that were first milked in 2000, this tendency concerned those cows that did not exceed $6000 \mathrm{~kg}$ as first calvers, while in the groups with higher milk yield levels longevity was found to decrease. The relationship between the milk yield of first calvers and longevity was determined using correlation coefficients $\left(r=0.21^{* *}\right.$ for the population that first calved in 1988 and $r=0.15^{* *}$ for the population that was first milked in 2000) (Table 7).

Table 5

Coefficients of correlation between age of cows at first calving and longevity

Korrelationskoeffizienten zwischen Erstkalbealter und Langlebigkeit

\begin{tabular}{lrr}
\hline Longevity traits & & Year of first calving \\
\hline Length of life (years) & 1988 & 2000 \\
Length of productive (years) & $0.061^{* *}$ & $0.039^{* *}$ \\
No. of calvings & $-0.019^{* *}$ & $-0.014^{* *}$ \\
\hline
\end{tabular}

**P $\leq 0.01$

Table 6

Effect of year of first calving and first lactation milk yield on cow longevity

Jahr der Erstabkalbung, Erstlaktationsleistung und Langlebigkeit

\begin{tabular}{|c|c|c|c|c|c|c|}
\hline Year & \multicolumn{2}{|l|}{$\begin{array}{l}\text { First lactation milk } \\
\text { yield, kg milk }\end{array}$} & $\mathrm{N}$ of cows & life, years & productive, years & $\mathrm{N}$ of calvings \\
\hline \multirow[t]{6}{*}{1988} & $\leq 4000$ & 1 & 6416 & 4.84 & 2.41 & 2.79 \\
\hline & $4001-5000$ & 2 & 4150 & 5.37 & 2.96 & 3.19 \\
\hline & $5001-6000$ & 3 & 2384 & 5.51 & 3.13 & 3.23 \\
\hline & $6001-7000$ & 4 & 1097 & 5.48 & 3.09 & 3.09 \\
\hline & $7001-8000$ & 5 & 423 & 5.54 & 3.17 & 3.02 \\
\hline & $>8000$ & 6 & 315 & 5.69 & 3.31 & 2.96 \\
\hline \multirow[t]{6}{*}{2000} & $\leq 4000$ & 7 & 1780 & 4.87 & 2.58 & 2.80 \\
\hline & $4001-5000$ & 8 & 1708 & 5.93 & 3.68 & 3.62 \\
\hline & $5001-6000$ & 9 & 1991 & 6.03 & 3.75 & 3.59 \\
\hline & $6001-7000$ & 10 & 1553 & 6.00 & 3.72 & 3.46 \\
\hline & $7001-8000$ & 11 & 1063 & 5.90 & 3.59 & 3.26 \\
\hline & $>8000$ & 12 & 1700 & 5.81 & 3.49 & 2.93 \\
\hline \multirow{9}{*}{\multicolumn{3}{|c|}{ Significance of differences }} & & $1-2,3,4,5,6,8,9,10,11,12^{* *}$ & $1-2,3,4,5,6,8,9,10,11,12^{* *}$ & $1-2,3,4,8,9,10,11^{* *}$ \\
\hline & & & & $2,3,4-7,8,9,10,11,12^{* *}$ & $2,3,4-7,8,9,10,11,12^{* *}$ & $2-7,8,9,10^{* *}$ \\
\hline & & & & $5-7,9 * * ; 5-10^{*}$ & $5-7,9^{* *}$ & $3-7,8,9^{* *}$ \\
\hline & & & & $6-7^{* *}$ & $6-7^{* *}$ & $4-8,9,10^{* *} ; 4-7^{*}$ \\
\hline & & & & $7-8,9,10,11,12^{* *}$ & $7-8,9,10,11,12^{* *}$ & $5,6-8,9 * * ; 5,6-10^{*}$ \\
\hline & & & & & $9-12^{*}$ & $7-8,9,10,11^{* *}$ \\
\hline & & & & & & $8,9-11,12^{* *}$ \\
\hline & & & & & & $10-11^{* *}$ \\
\hline & & & & & & $11-12^{*}$ \\
\hline
\end{tabular}

${ }^{*} P \leq 0.01,{ }^{*} P \leq 0.05$ 
Table 7

Coefficients of correlation between first lactation yield and longevity

Korrelationskoeffizienten zwischen Erstlaktationsleistung und Langlebigkeit

\begin{tabular}{lll}
\hline Longevity traits & 1988 & Year of first calving \\
\hline Length of life (years) & $0.208^{* *}$ & 2000 \\
Length of productive (years) & $0.219^{* *}$ & $0.150^{* *}$ \\
No. of calvings & $0.125^{* *}$ & $0.143^{* *}$ \\
\hline
\end{tabular}

${ }^{*} P \leq 0.01$

The analysis of longevity according to reasons for culling demonstrated that the cows culled for old age had the longest lifespan, the greatest length of productive life and the greatest number of calvings (Table 8). Slightly better results were obtained for cows that were first milked in 2000: they formed $1.3 \%$ of all cows compared to $0.5 \%$ for cows that first calved in 1988. While old age was the least frequent reason for removal of cows from the herd, infertility was the most frequent reason, especially among cows that first calved in 2000 . The lifespan of cows culled for infertility ranged from 5.29 (1988 population) to 5.89 years (2000 population). These cows had a longer lifespan compared to those sold for further breeding or culled for low milk production or accidents. The cows culled for low milk production had a slightly shorter lifespan compared to the average lifespan in the populations studied (Table 1 and 8). It was also shown that longevity of cows removed from the herd for low milk production decreased during 1988-2000. Considering that selection in the active population should be performed mainly to improve milk yield, it seems that mostly young cows should be culled for low milk production. This will enable rapid production progress to be obtained.

\section{Discussion}

The average lifespan of the cows was 5.54 years (with average length of productive life being 3.18 years) and showed significant differences within the treatment factors analysed (Table $1,2,3,4,6,8)$. It appears from the study of milk production in successive lactations (SAWA 2001) that cows can only be culled after 3-5 lactations. JUSZCZAK et al. (2003) reported that the cost of all milk produced by cows over three lactations equals its market value and profits can only be obtained from fourth lactation on. A similar view is held by KANCER et al. (2001), who report that it is profitable to use cows for at least four lactations.

Longevity is one of the most important indicators of cow performance that has recently been included in selection indices (SÖLKNER et al. 2000, BIFFANI et al. 2002). Considering that the cows' age of culling has been decreasing for many years (LITWIŃCZUK et al. 1984, SAWA 1998, JUSZCZAK et al. 2001, WROŃSKI et al. 2003, SOBEK et al. 2006), the results obtained are optimistic due to improved longevity of the cows that first calved in 2000 compared to the cows that were first milked in 1988 (Table 1).

In the late 1980s and early 1990s cattle breeding and husbandry in Poland underwent important changes resulting from structural transformation and the liquidation of many state, collective and individual farms (TRELA and LITWIŃCZUK 1999). One of the beneficial outcomes of these changes was that the concentration of cows in farms has gradually increased. 
Table 8

Effect of year of first calving and reasons for culling from the herd on cow longevity Jahr der Erstabkalbung, Abgangsursachen und Langlebigkeit

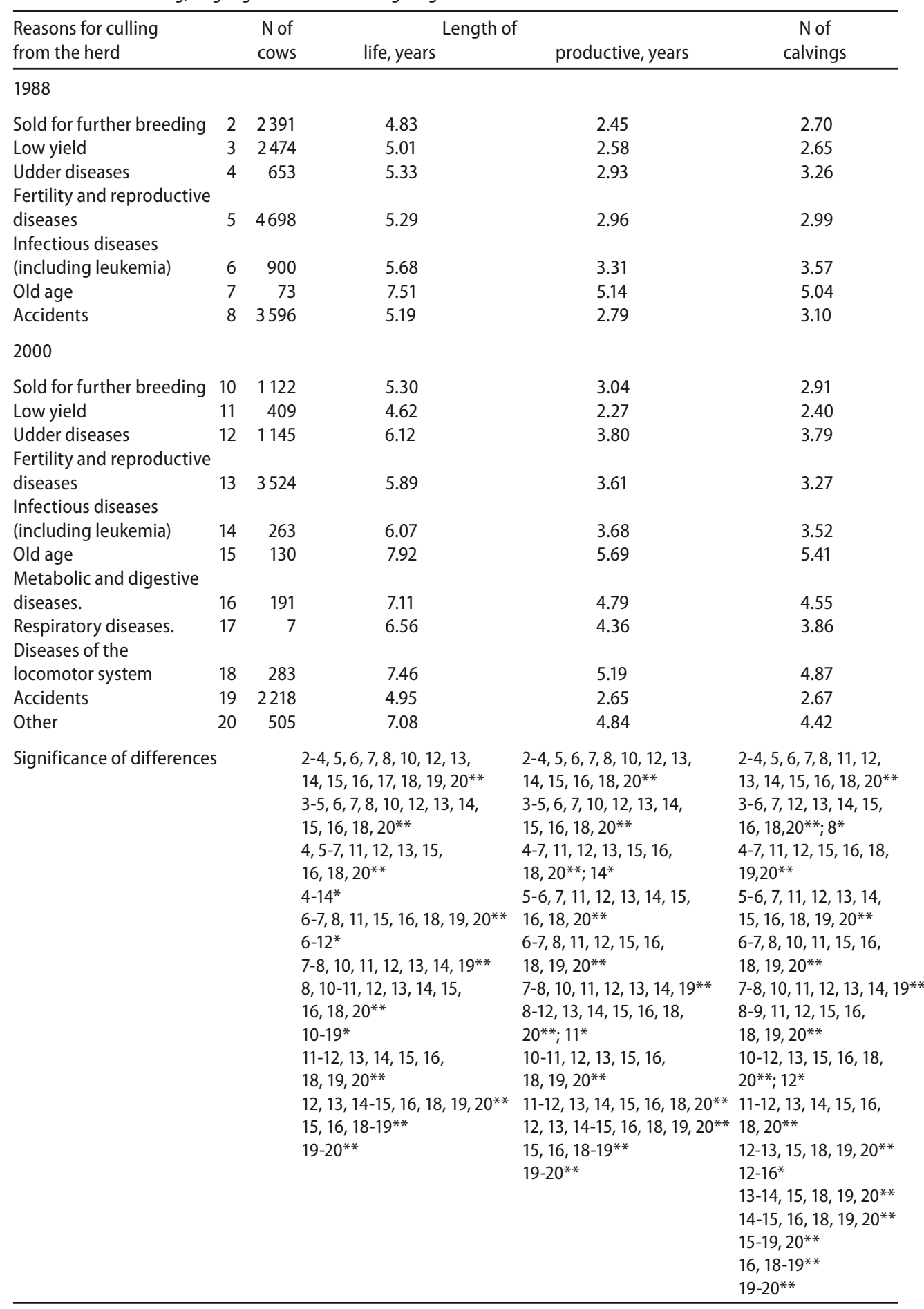


Our study showed that the greatest changes concerned the proportion of cows from herds with $\leq 10$ and $>200$ animals (Table 2). Among the cows that first calved in 2000, the proportion of those from smallest herds decreased 2-fold in relation to the population that was first milked in 1988, while the proportion of cows from largest herds increased over 3-fold. Longevity showed greatest improvement in cows from herds of 10.1-20 and 20.1-100 animals. WROŃSKI et al. (2003) reported that among the cows that first calved in 1991-1993 in the Białostockie and Olsztyńskie provinces, cows from herds of 11-30 animals had the longest lifespan. According to the same authors, this could be due to better care and handling of animals compared to large herds, as well as from the better organization and mechanization of work compared to small herds.

The shortest lifespan and length of productive life, found in our study for cows from low-productive herds that first calved in 1998 (Table 3), is evidence that environmental conditions did not match animal needs. The proportion of cows that were first milked in 2000 in herds with $\leq 4000 \mathrm{~kg}$ milk production decreased 5 -fold. A significant effect of herd milk production level on cow longevity was also reported by ŁUKASZEWICZ and KRENCIK (1994).

The tendency towards improved cow longevity with higher age of first calving (Table 4 and 5) is in agreement with the findings of WIELGOSZ-GROTH et al. (1996). According to SOBEK et al. (2006), the lifespan of cows can be slightly increased in proportion to the age of cows at first calving $\left(r=0.101^{* *}\right)$.

The present results (Table 6 and 7) and those of other authors (SZWACZKOWSKI and JANICKI 1993, TEKERLI and KOCAK 2009) indicate that lifetime milk production depends on first lactation milk yield. Considering the short lifespan of cows, it is stated that the high first lactation milk yield has a positive effect on longevity. It was shown, however, that excessive milk production of first calvers $(>7000 \mathrm{~kg}$ ) shortens their lifespan and productive life. JUSZCZAK et al. (1994) point out that the length of productive life decreases already with first lactation milk yield increasing $>5000 \mathrm{~kg}$. JANUŚ and BORKOWSKA (2004) did not show any significant differences between lifespan and length of productive life, but found that these periods decreased with increased first lactation milk yield (cows with first lactation yields $>6000 \mathrm{~kg}$ had the shortest lifespan and length of productive life). BRZOZOWSKI et al. (2003) reported that first lactation yield has no effect on the length of cow's productive life in the herd. DUCROCQ et al. (1988) and SAWA and KRĘŻEL-CZOPEK (2009) showed a positive genetic correlation between first lactation yield and length of cows' productive life, while ŁUKASZEWICZ and KRENCIK (1994) obtained negative (and low) correlations between the milk yield of first calvers and survival traits.

Cow culling is an important issue from the breeding and economic point of view. Cows were culled from the herd mainly because of infertility (Table 8 ). For this reason, about $31 \%$ cows that first calved in 1988 and $36 \%$ cows that were first milked in 2000 were removed. JUSZCZAK et al. (2003) note that culling due to infertility increases with the increasing proportion of Holstein-Friesian genes. Our results confirm the findings of PAWLINA et al. (1997) that cows culled for infertility had a longer lifespan than those culled for low milk production and a shorter lifespan than cows removed for other reasons. Likewise, DORYNEK et al. (2005), who compared cow longevity with regard to reasons for culling showed that animals culled for infertility had the longest lifespan and length of productive 
life. PAWLINA et al. (1997) showed for high-yielding cattle from 8 herds in the Lower Silesia and Opole regions that cows culled for low milk production had the shortest lifespan. Similar observations were made in the present study. The early elimination of mediumyielding cows is confirmed by the genetic correlations calculated by DUCROCQ et al. (1988) between longevity traits and first lactation milk yield. Cows culled for udder diseases lived 0.15 (1988 population) and 0.38 years longer (2000 population) than the average for the population studied (Table 1 and 8). This supports the findings of OTWINOWSKA-MINDUR (2008) and SAWA and PIWCZYŃSKI (2002), who showed the incidence of mastitis to increase in older cows. According to BAKKEN (1981), the increasing age of cows increases the risk of new infections while reducing the chances for recovery. The increased proportion of cows culled for udder diseases (from $4.4 \%$ in the 1988 population to $11.7 \%$ in the 2000 population) is perhaps related to the increasing demands that milk producers have to meet regarding milk quality.

In improved longevity of the cows that first calved in 2000 in relation to those that were first milked in 1988 is desirable. The lifespan and length of productive life increased the most (by about 1 year) in herds of up to 20 cows, in herds with the lowest production level (by about 0.85 years), in herds of cows that first calved before 24 months of age up (by about 1 year) and in herds of cows that yielded $4000-7000 \mathrm{~kg}$ milk as first calvers (by about 0.5 years). Shortening the length of productive life in cows culled for low milk production (by 0.3 years) is probably one of the reasons for considerable production progress attained in cows in recent years. Age of cows at first calving and first lactation milk yield were significantly correlated to cow longevity.

\section{References}

Bakken G (1981) Subclinical mastitis in Norwegian dairy cows. Acta Agric 31, 273-86

Baumung R, Sölkner J, Gierzinger E, Willam A (2001) Ecological total merit index for an Austrian dual purpose cattle breed. Arch Tierz 44, 5-13

Biffani S, Samore AB, Canavesi F (2002) The new selection index for the Italian Holstein. Interbull Bull 29, 142-6

Brzozowski P, Empel W, Zdziarski K, Grodzki H (2003) Influence of cows' health and their milk yield during first lactation on their productive life and life-time milk yield. Med Wet 59, 626-9 [in Polish]

Dakay I, Marton D, Bene S, Kiss B, Zsuppan Z, Szabo F (2006) The age at first calving and the longevity of beef cows in Hungary. Arch Tierz 49, 417-25

Dorynek Z, Pytlewski J, Antkowiak I (2005) Culling causes and lifetime performance of Holstein-Friesian cows. Rocz. Nauk PTZ 1, 17-26 [in Polish]

Ducrocq VP, Quaas RL, PollakEJ, Casella G (1988) Length of productive life in dairy cows. 2. Variance component estimation and sire evaluation. J Dairy Sci 71, 3071-9

Freyer G, Erhardt G (2000) First results of a MAS study in dairy cattle with respect to longevity. Arch Tierz 43, 241-7

Harder B, Junge W, Bennewitz J, Kalm E (2004) Investigations on breeding plans for organic dairy cattle. Arch Tierz 47, 129-39

Januś E, Borkowska D (2004) Relationship between milk yield in the first lactation and the indices of production traits, fertility, performance lenght and the reasons for curling cows. Zesz Nauk Prz Hod 74, 103-9 [in Polish] 
Juszczak J, Hibner A, Zachwieja A, Tomaszewska A, Krzyśków S (1994) Issue of high milk efficiencies. Anim Prod Review 4, 3-5

Juszczak J, Hibner A, Tomaszewski J (2001) The dynamics of changes in performance indices in a holsteinfriesian cross-breed cow herd. Med Wet 57, 284-7 [in Polish]

Juszczak J, Hibner A, Ziemiński R, Tomaszewski A (2003) Causes and consequences of early culling of dairy cows. Med Wet 59, $432-5$ [in Polish]

Kancer FHJ, Mostert BE, Theron HE (2001) The effect of calving season and age at calving on production traits of South African dairy cattle. South Afr J Anim Sci 31, 205-14

Litwińczuk Z, Borkowska D, Oberda A (1984) Observations on the duration of milk production in cows and on causes of culling in a reproduction cowsed. Med Wet 40, 122-5 [in Polish]

Łukaszewicz M, Krencik D (1994) Heritability coefficients of longevity traits at different milk production levels in dairy cattle. Anim Sci and Rep 12, 27-32

Meszaros G, Fuerst C, Fuerst-Waltl B, Kadlecik O, Kasarda R, Solkner J, (2008) Genetic evaluation for length of productive life in Slovak Pinzgau cattle. Arch Tierz 51, 438-48

Otwinowska-Mindur A, Gierdziewicz M, Ptak E (2008) Effect of year, season and age of calving on somatic cell score in Polish Holstein-Friesian cows of Black-and-White variety. Rocz Nauk PTZ 4, 29-36 [in Polish]

Pawlina E, Nowicki B, Hibner A, Kruszyński W (1997) Longevity and production traits of culled Red and White cows. Zesz Nauk AR Wrocław 307, 105-13 [in Polish]

SAS (2004) SAS User's guide 9.1. SAS Institute Inc., Cary, NC, USA

Sawa A (1998) Genetic and environmental effects upon dairy cows performance in particular life periods. Zesz Nauk ATR Bydgoszcz 88, 1-69 [in Polish]

Sawa A (2001) Effect of first lactation yield on life performance of cows. EJPAU Anim Husb 4 I 2

Sawa A, Piwczyński D (2002) Somatic cell count and milk yield and composition in Black and White $\times$ HolsteinFriesian cows. Med Wet 58, 636-40 [in Polish]

Sawa A, Krężel-Czopek S (2009) Effect of first lactation milk yield on efficiency of cows in herds with different production levels. Arch Tierz 52, 7-14

Skrzypek R (1978) Observation over the milk cows longevity and possibility of her improvment. Prz Hod 8, 16-8 [in Polish]

Sobek Z, Dymarski I, Rzemykowska M (2006) The change in age of the first calving and period of using of dairy cattle from ZZD IZ Pawłowice. Acta Sci Pol Zoot 5, 105-20 [in Polish]

Sölkner J, Miesenberger J, Willam A, Fuerst C, Baumung R (2000) Total merit indices in dual purpose cattle. Arch Tierz 43, 597-608

Swalve HH (2003) New breeding approaches for functional traits. Arch Tierz 46, 63-71

Szwaczkowski T, Janicki C (1993) Level of first lactation milk traits and length of performance of dairy cows. PTPN Pr Kom Nauk Rol i Leś LXXC, 207-11 [in Polish]

Tekerli M, Kocak S (2009) Relationship between production and fertility traits in first lactation and life time performances of Holstein cows under subtropical condition. Arch Tierz 52, 364-70

Trela J, Litwińczuk Z (1999) Cattle management and breeding in Poland. Zesz Nauk Prz Hod 47, 11-28 [in Polish]

Wielgosz-Groth Z, Kijak Z, Cichocki M, Mazek J (1996) The effect of age first calving on rate and causes of culling cows in the region of North-Eastern Poland. Scient Symp "Cattle breeding in Poland - history and future" Olsztyn, 193-203 [in Polish]

Wroński M, Cieśluk S, Kosakowska J, Cichocki M (2001) Effect of number of herd on efficiency of use of Blackand-White cows. Anim Sci 39, 202-8 [in Polish]

Żarnecki A, Norman HD, Jamrozik J (1997) Lifetime yield and herd life for crosses of Friesian strains in Poland. J Anim Feed Sci 6, 1-11 
Received 19 March 2009, accepted 17 January 2010.

Corresponding author:

ANNA SAWA

email: sawa@utp.edu.pl

Department of Cattle Breeding, Faculty of Animal Breeding and Biology, University of Technology and Life Sciences in Bydgoszcz, Mazowiecka 28, 85-084 Bydgoszcz, Poland 